\title{
7 \\ The Impact of International Commissions of Inquiry on the Proceedings before the International Criminal Court
}

\author{
TRIESTINO MARINIELLO
}

\subsection{INTRODUCTION}

$\mathrm{O}$

N 18 SEPTEMBER 2004, the United Nations (UN) Security Council requested the Secretary General to appoint an international commission of inquiry in order to investigate reports of violations of international humanitarian law and human rights law in Darfur. ${ }^{1}$ In February 2008, the Kenyan government decided to establish an international commission of inquiry to provide recommendations on the measures in bringing to justice those persons responsible for acts of violence that occurred immediately after the presidential elections results were announced. $^{2}$ In 2011, the Human Rights Council decided to dispatch two commissions of inquiry on the allegations of serious violations of human rights law that occurred in Libya and Ivory Coast. ${ }^{3}$

These commissions were vested with the authority to make a first legal evaluation of the facts that occurred in the situations in question. Despite the fact that they were established by different bodies and had to deal with very different contexts, their mandates presented a common denominator: they received an accountability driven-mandate. Indeed, rather than being

1 UN Security Council Resolution 1564 (2004) 12.

2 The Commission of Inquiry into the Post Election Violence began on 23 May 2008 with an announcement published in the Kenya Gazette Notice No 4473 vol cx-no 41.

3 The International Commission of Inquiry on Libya was created by the Human Rights Council at its $15^{\text {th }}$ session on 25 February 2011 by Resolution S-15/1, UN Doc A/HRC/S$15 / 1,11$. The International Commission of Inquiry on Côte d'Ivoire was established by UN Human Rights Council Resolution 16/25 on 13 April 2011, UN Doc A/HRC/RES/16/25, 10. 
mere fact-finding missions they were instructed to identify the alleged perpetrators of international violations and ensure that they were held accountable.

This chapter critically assesses the relationship between the Sudan, Kenya, Libya, and Ivory Coast commissions of inquiry and the International Criminal Court (ICC). Such commissions were tasked to investigate allegations of international violations within the context of situations that are still open before the ICC. Therefore, this study examines the mandate and work of these commissions vis-à-vis (pre-trial) decisions of the ICC. In so doing, it aims to explore whether and to what extent the commissions' investigations impacted upon the different phases of the ICC's pre-trial proceedings, namely from the referral of a situation to the confirmation of charges. Since no case related to the situations in Sudan, Kenya, Libya and Ivory Coast has been completed, this study does not investigate the weight of the commissions' information at the trial stage.

In light of this ambition, section 7.2 provides a brief description of the evolution of the role of international commissions of inquiry from plain fact-finding to (quasi) judicial bodies, entrusted with the authority to provide legal evaluation of the relevant facts and secure prosecution-oriented criminal evidence. Section 7.3 offers a general overview on the use of international criminal law by international commissions of inquiry since 1993. It examines how international criminal law has been applied not only by those UN Commissions which were explicitly instructed to assess the perpetration of international crimes, but also by fact-finding missions whose mandate was confined to ascertaining violations of international human rights law and international humanitarian law.

Following a presentation of the main international criminal law findings by the commissions of inquiry in Sudan, Kenya, Libya and Ivory Coast (section 7.4), section 7.5 provides the first comprehensive analysis of the relevant pre-trial jurisprudence related to the situations in question, in order to assess the significance of the commissions' sources in the different phases of the ICC proceedings. In particular, it shows how the commissions' information, although not binding on the ICC, played a key role within the context of both pre-investigative and investigative phases before the Court. In light of the relevance that commissions' documents assumed in the decisions to issue arrest warrants or summons under Article 58 of the Rome Statute, Section 7.6 argues the necessity that the Prosecutor does not heavily rely on the fact-finding sources. As factfinding missions' information appeared very persuasive to the decisions under Article 58, this section recommends that the Prosecutor submit the application for an arrest warrant or summons only if she is able to conduct an independent investigation, producing evidence which might corroborate third-party findings. 


\subsection{THE EMERGING SYNERGY BETWEEN FACT-FINDING MISSIONS AND INTERNATIONAL CRIMINAL JUSTICE: THE COMMISSION OF EXPERTS ON THE FORMER YUGOSLAVIA}

The functions of international commissions of inquiry have significantly evolved in the last 30 years. Traditionally, the role of commissions was confined to making factual determinations, in order to encourage the peaceful resolution of international disputes. ${ }^{4}$ As enshrined in Article 9 of the 1907 Hague Convention for the Pacific Settlement of International Disputes, when an international dispute exists because of a difference of opinion on points of fact, states should establish an international commission of inquiry to 'facilitate a solution of these differences by elucidating the facts by means of an impartial and conscientious investigation'. The role of factfinding missions was confined to the presentation of findings of a factual nature, while the possibility of drawing legal conclusions exceeded the commissions' mandates.

The Charter of the United Nations confirms this traditional understanding of fact-finding missions as enshrined in the 1907 Hague Conventions. In particular, according to Article 33 of the UN Charter, fact-finding missions may constitute a distinct means for the resolution of a dispute. The UN organs may, therefore, rely on detailed fact-finding to gather information, which could be useful for exercising effectively their role in restoring and maintaining international peace and security.

The 1991 Declaration on Fact-finding by the United Nations in the Field of the Maintenance of International Peace and Security recognised this function of fact-finding missions:

In performing their functions in relation to the maintenance of international peace and security, the competent organs of the [UN] should endeavour to have full knowledge of all relevant facts. To this end they should consider undertaking fact-finding activities. ${ }^{5}$

The establishment of a Commission of Experts for the former Yugoslavia (Yugoslavia Commission) in 1993 represented a turning point, as it introduced a new model of commission vested with authority to investigate violations of international law and recommend measures to ensure

${ }^{4}$ For a detailed historical-comparative analysis of commissions of inquiry, see LJ van den Herik, 'An Inquiry into the Role of Commissions of Inquiry in International Law: Navigating the Tensions between Fact-Finding and Application of International Law' (2014) 13 Chinese Journal of International Law 507. See also LJ van den Herik and C Harwood, 'Sharing the Law: The Appeal of International Criminal Law for International Commissions of Inquiry' in P Alston and S Knuckey (eds), The Transformation of Human Rights Fact-Finding (Oxford, Oxford University Press, 2016) 233.

5 UN General Assembly Resolution 46/59, Declaration of Fact-Finding by the United Nations in the Field of the Maintenance of International Peace and Security 1991, UN Doc A/RES/46/59 (9 December 1991) 1. 
accountability for those violations. ${ }^{6}$ Indeed, the Yugoslavia Commission was entrusted by the UN Security Council with the power to inquire into violations of the Geneva Conventions and other violations of international humanitarian law committed in the territory of the former Yugoslavia. ${ }^{7}$ The same Commission decided to extend its analysis into violations of international criminal law and recommended the establishment of an international criminal tribunal (ICT) ${ }^{8}$ In so doing, it performed the investigation in order to secure prosecution-oriented criminal evidence. The Commission also clarified legal concepts related to the investigated facts, such as genocide, crimes against humanity, command responsibility, superior orders, reprisals, rape and other forms of sexual assault. ${ }^{9}$

The interim report of the Commission triggered the establishment of the first ICT after Nuremberg and Tokyo. ${ }^{10}$ Although there was no formal institutional link between the Commission and the International Criminal Tribunal for the former Yugoslavia (ICTY), the Commission's work had a significant influence on the law and practice of the Court. ${ }^{11}$ With respect to the applicable law, the ICTY Statute included legal formulations, as indicated by the Commission of Inquiry. This is true in relation to the definition of command responsibility and the concept of superior orders, which, as suggested by the commissions, do not represent a ground to exclude criminal liability of the subordinate, but may be taken into account as a mere mitigating circumstance. ${ }^{12}$ With regard to the influence on the practice of the ICTY, the Prosecutor could start his work on the basis of the material collected by the Commission of Experts. As argued by Frulli, 'the findings of the Commission contributed greatly to a quick and efficient start of the work of the ICTY prosecutor, who took office almost fourteen months after the establishment of the ICTY' ${ }^{\prime 13}$

In particular, the relevance of the information collected by the Commission to the ICTY lay in the fact that it revealed that grave breaches of the Geneva Conventions and other violations of international humanitarian law had been committed on a large scale. ${ }^{14}$ In addition, the Commission

${ }^{6}$ UN Security Council Resolution 780 (1992), UN Doc S/RES/780 (1992) (6 October 1992) 2.

7 ibid.

8 Interim Report of the Commission of Experts Established Pursuant to Security Council Resolutions 780 (1992), UN Doc S/25274 (10 February 1993) (Yugoslavia Interim Report).

9 Final Report of the Commission of Experts Established Pursuant to Security Council Resolution 780 (1992), UN Doc S/1994/674 (27 May 1994) (Yugoslavia Final Report).

10 Yugoslavia Final Report (n 9).

11 M Frulli, 'Fact-Finding or Paving the Way to Criminal Justice? Some Reflections on the UN Commissions of Inquiry' (2012) 10 Journal of International Criminal Justice 1323, 1327.

12 See the Yugoslavia Interim Report (n 8) 51-53 and the ICTY Statute, Art 7.

13 Frulli (n 11) 1327.

14 Yugoslavia Final Report (n 9) 311. 
provided a significant contribution to the investigation of international violations as it found the systematic nature of the commission of rape and sexual assault. ${ }^{15}$

\subsection{THE USE OF INTERNATIONAL CRIMINAL LAW BY INTERNATIONAL COMMISSIONS OF INQUIRY: A GENERAL OVERVIEW}

The vast majority of UN commissions of inquiry established since 1993 followed on from the Yugoslavia experience, as their mandates were no longer confined to factual determinations, but also included the possibility for providing legal evaluations, in particular to investigate whether the relevant facts constituted violations of international law. It can be argued that the Yugoslavia Commission started a process of 'juridification' or 'criminalisation' of commissions of inquiry, ${ }^{16}$ instructed to go beyond the ascertainment of the responsibilities of legal entities as states and nonstate armed groups and make a preliminary evaluation of the facts based on international legal parameters, so that individuals who were responsible for the violations are held accountable.

Some commissions were expressly requested to ascertain whether the investigated facts amounted to international crimes. ${ }^{17}$ Other commissions were instructed to assess international humanitarian law and human rights violations. ${ }^{18}$ Still, they decided to cover also alleged violations of international criminal law, on the basis of the possibility of framing international humanitarian law and human rights violations as international crimes.

15 Yugoslavia Final Report (n 9) pt IV, section F.

16 PG Alston, 'The Criminalization of International Human Rights Fact-Finding' (Key Note Address at the Conference on Fact-finding on Gross Violations of Human Rights During and After Conflicts, Oslo, Norwegian Centre for Human Rights, 17-18 November 2011). For a critical analysis of this process of 'criminalisation' of international commissions of inquiry, see Ch 6: C Schwöbel-Patel, 'Commissions of Inquiry: Courting International Criminal Courts and Tribunals'.

17 See, inter alia, UN Security Council Resolution 935 (1994), Commissions of Experts for Rwanda (1 July 1994); Darfur Commission (n 1); Independent International Commission of Inquiry on the Syrian Arab Republic, UN Doc A/HRC/S-17/L.1 (22 August 2011); Commission of Inquiry on Human Rights in the Democratic People's Republic of Korea (DPRK), UN Doc A/HRC/RES/22/13 (21 March 2013).

18 See, inter alia, Libya Commission (n 3); UN Human Rights Council Resolution S-9/1, Independent Commission of Inquiry on the 2014 Gaza Conflict (12 January 2009). For a detailed analysis of the migration of international criminal law concepts into the work of international commissions of inquiry, see also, D Jacobs and C Harwood, 'International Criminal Law outside the Courtroom: The Impact of Focusing on International Crimes for the Quality of Fact-Finding by International Commissions of Inquiry' in M Bergsmo (ed), Quality Control in Fact-Finding (Torkel Opsahl Academic EPublisher, 2013) 325. 
With respect to fact-finding missions established to assess the perpetration of international crimes, for instance, a few months after the Yugoslavia Commission the UN Security Council requested the Rwanda Commission to gather evidence of grave violations of international humanitarian law committed in the territory of Rwanda, including the evidence of possible acts of genocide (emphasis added). ${ }^{19}$ In contrast to the Yugoslavia experience, it does not appear that the Rwanda Commission played any role in prompting the establishment of the international criminal tribunal. Indeed, the International Criminal Tribunal for Rwanda was established before the submission of the Commission's final report. ${ }^{20}$ However, the final findings of the Commission confirmed that genocide and other systematic, widespread and flagrant violations of international humanitarian law had been perpetrated in Rwanda. ${ }^{21}$ Similarly, the Darfur Commission was instructed, inter alia, to ascertain whether acts of genocide had occurred, ${ }^{22}$ while the Syria Commission was tasked with identifying those responsible for international violations, particularly crimes against humanity. ${ }^{23}$ The Democratic People's Republic of Korea Commission was mandated to 'investigate systematic, widespread and grave violations of human rights, with a view to ensuring full institutional and personal accountability, in particular where violations may amount to crimes against humanity (emphasis added). ${ }^{24}$

Other commissions were established to determine alleged violations of international humanitarian law and/or human rights violations. However, even if their mandates did not explicitly include international criminal law, these commissions also investigated allegations of international crimes. The commissions justified their decisions to exceed their mandates by stressing that international criminal law constitutes an enforcement measure for serious violations of human rights and international humanitarian law. For instance, the International Commission of Inquiry for Libya stated that international criminal law is the 'means of enforcement at the international level of penalties for grave violations of customary law, [human rights] and serious violations of [international humanitarian law] which are recognized as attracting individual liability' ${ }^{25}$

19 Rwanda Commission (n 17).

20 The Report of the Commission was finalised on the 9 December 1994, whilst the ICTR had already been established on 8 November 1994. See Final Report of the Commission of Experts Submitted Pursuant to Resolution 935 (1994), UN Doc S/1994/1405 (9 December 1994) Annex.

21 ibid.

22 Darfur Commission (n 1).

23 Syria Commission (n 17) 12.

24 See DPRK Commission (n 17) 5.

25 UN Human Rights Council, Report of the International Commission of Inquiry to investigate all Alleged Violations of International human rights law in the Libyan Arab Jamahiriya, UN Doc A/ HRC/17/44 (1 June 2011) 23 (Libya Report). 
The so-called Goldstone Commission, instructed to investigate violations of international humanitarian law and human rights during the Gaza Conflict, found that:

International criminal law has become a necessary instrument for the enforcement of IHL and (human rights). Criminal sanctions have a deterrent function and offer a measure of justice for the victims of violations. The international community increasingly looks to criminal justice as an effective mechanism of accountability and justice in the face of abuse and impunity. The Mission regards the rules and definitions of international criminal law as crucial to the fulfilment of its mandate to look at all violations of IHL and IHRL by all parties to the conflict. ${ }^{26}$

The Eritrea Commission of Inquiry explicitly admitted that its mandate was confined to investigate only violations of human rights and, as such, did not establish whether such violations amounted to international crimes. ${ }^{27}$ However, it concluded that international crimes might have been committed and recommended further investigations. ${ }^{28}$

The commission established by the UN Human Rights Council to investigate violations of international humanitarian law and human rights law, resulting from the interception by Israeli forces of the humanitarian aid flotilla bound for Gaza (Flotilla Commission), concluded that these violations constituted (war) crimes under Article 147 of the Fourth Geneva Convention. $^{29}$

In the proposal to establish a fact-finding mission in East Timor, the same UN Commission on Human Rights clearly stated that 'all persons who committed or authorised violations of human rights or international humanitarian law were individually responsible and accountable for those violations' ${ }^{30}$ In its final report, the East Timor Commission stated that victims have a right to an effective remedy for violations of human rights, which includes also the state's responsibility to use criminal law measures against those responsible of such violations. ${ }^{31}$

Several fact-finding missions established after the Yugoslavia Commission received an explicit accountability driven-mandate, since they were

26 Report of the United Nations Fact-Finding Mission on the Gaza Conflict, UN Doc A/ $\mathrm{HRC} / 12 / 48$ (25 September 2009) 286.

27 Report of the Commission of Inquiry on Human Rights in Eritrea, UN Doc A/HRC/29/42 (4 June 2015) 8.

28 ibid.

29 Report of the international fact-finding mission to investigate violations of international law, including international humanitarian and human rights law, resulting from the Israeli attacks on the flotilla of ships carrying humanitarian assistance, UN Doc A/HRC/15/21 (27 September 2010) 265.

30 See The Commission on Human Rights, Report of the Fourth Special Session, E/CN.4/ RES/1999/S-4/1 (27 September 1999).

31 Report of the International Commission of Inquiry on East Timor, UN Doc A/54/726, S/2000/59, 148. 
instructed to ensure that those responsible of such violations were held accountable. For instance, the Burundi Commission was also established to recommend measures to bring to justice persons responsible for the assassination of the President of Burundi on 21 October 1993, the massacres and other related serious acts of violence', 32 and the Sri Lanka Commission was requested to investigate allegations of the crimes perpetrated in order to avoid impunity and ensuring accountability. ${ }^{33}$ The Cambodia Commission was mandated to 'determine the nature of the crimes committed by Khmer Rouge leaders' and 'to explore legal options for bringing them to justice before an international or national jurisdiction' ${ }^{34}$

Occasionally, this accountability-driven mandate included also the authority to identify those responsible for the crimes committed. The Central African Republic Commission, established by the UN Security Council in 2013, was entrusted with the identification of perpetrators of violations of international humanitarian law and international human rights law, and the assessment of their possible criminal responsibility, with a view to ensuring that those responsible were held accountable. ${ }^{35}$ The 2009 Guinea Commission was established to ascertain which crimes had been committed and identify their perpetrators. ${ }^{36}$

\subsection{ACCOUNTABILITY-DRIVEN MANDATES IN PRACTICE: THE CASES OF SUDAN, KENYA, IVORY COAST AND LIBYA}

The UN commissions of inquiry in Sudan, Libya, and Ivory Coast were also instructed to ensure accountability and identify the alleged perpetrators of international violations. Before assessing the relationship between commissions of inquiry and international criminal proceedings, the next section will briefly discuss the findings of these fact-finding missions, as they investigated the alleged commission of international crimes within the context of situations that are still open before the International Criminal Court. For the same reason, the analysis will cover also the work of the

32 The Commission was created by UN Security Council Resolution 1012, UN Doc S/RES/1012 (28 August 1995).

33 See UN Doc A/HRC/25/L.1/Rev.1, 10(b).

34 The Group of Experts for Cambodia was established pursuant to UNGA Resolution 52/135 (27 February 1998), UN Doc A/RES/52/135(1).

35 See UN Doc S/RES/2127 (2013).

36 On 28 September 2009, a violent crackdown on a pro-democracy rally in the Guinean capital of Conakry resulted in the deaths of at least 150 people as well other violent incidents. The Commission was mandated to establish the facts and circumstances of the events of 28 September 2009 and the related events in their immediate aftermath, qualify the crime perpetrated, determine responsibilities and, where possible, identify those responsible. See Letter from the Secretary General, UN Doc S/2009/556 (28 October 2009). 
international commission of inquiry in Kenya, the so-called Waki Commission, which significantly paved the road to international criminal justice.

In line with the evolution of the role and functions of commissions of inquiry post-1993, beyond being plain fact-finding missions, these commissions were called to ensure that those responsible for heinous conduct were brought to justice. As we will analyse in the following subsections, the mandate of the Darfur Commission provided that it had to identify the perpetrators of violations of international humanitarian law and human rights law with a view to ensuring that those responsible were held accountable. In Kenya, according to the terms of reference, the Commission had to issue recommendations on the measures with regard to bringing to justice those persons responsible for acts of violence occurring immediately after the presidential elections results were announced. The Libya Commission had to identify those responsible for violations of international human rights law and ensure that those individuals responsible were held accountable. In Ivory Coast, the Commission also had to identify those responsible for serious abuses and violations of human rights law committed in Côte d'Ivoire following the presidential election of 28 November 2010.

\subsubsection{The UNSC Darfur Commission}

The Darfur Commission admitted that in classifying the facts according to international criminal law, it adopted an approach proper to a judicial body. ${ }^{37}$ It excluded the commission of genocide, as it stressed that attacking, killing and forcibly displacing members of some tribes was not perpetrated in order to annihilate, in whole or in part, a racial, ethnic, national or religious group, as required by the genocide definition. ${ }^{38}$ However, the Commission concluded that the investigated facts amounted to war crimes and crimes against humanity. ${ }^{39}$ With respect to these core crimes, the Commission provided a detailed analysis of their contextual elements and underlying offences. Indeed, it reported the existence of the armed conflict for war crimes, ${ }^{40}$ and of widespread or systematic attacks against the civilian population for crimes against humanity. ${ }^{41}$ It also defined the

37 Report of the International Commission of Inquiry on Darfur to the United Nations SecretaryGeneral (25 January 2005) 14 (Darfur Report).

38 Darfur Report (n 37) 518.

39 Darfur Report (n 37) section VI (1-6).

40 Darfur Report (n 37) 74-76.

41 Darfur Report (n 37) section VI (1-6). 
nature of the conflict, in order to establish which set of rules of international humanitarian law were applicable in each case. ${ }^{42}$

The Commission also found that most attacks were deliberately and indiscriminately directed against civilians. ${ }^{43}$ Moreover, it relied on the jurisprudence of ad hoc tribunals and the Statute of the ICC in classifying the relevant facts as underlying offences of international crimes. ${ }^{44}$ In particular, it ascertained the perpetration of underlying offences of war crimes and crimes against humanity, such as killing of civilians, torture, enforced disappearances, destruction of villages, rape and other forms of sexual violence, pillaging and forced displacement. ${ }^{45}$

The Commission claimed its authority not only to find material perpetrators of alleged crimes but also those who bore the greatest responsibility. Therefore, it identified a number of possible suspects for serious violations of international human rights law and international humanitarian law. However, it decided to withhold the names of these suspects from the public domain, on the basis of

1) the importance of the principles of due process and respect for the rights of the suspects; 2) the fact that the Commission has not been vested with investigative or prosecutorial powers; and 3) the vital need to ensure the protection of witnesses from possible harassment or intimidation. ${ }^{46}$

The list of likely suspects of international crimes was filed with the UN Security Council, with the recommendation that it should have been delivered to the ICC Prosecutor for future investigations and possible indictments. ${ }^{47}$

\subsubsection{The International Commission of Inquiry into the Post-Election Violence in Kenya}

In Kenya, the so called Waki Commission of Inquiry reached the conclusion that crimes against humanity had been committed in Kenya after the 2007 presidential elections. ${ }^{48}$ In particular, the Commission found that murder, destruction of property, serious injuries, sexual violence, and forcible transfer of population had been perpetrated..$^{49}$ According to the

42 Darfur Report (n 37) 74-76.

43 Darfur Report (n 37) 238-68.

44 Darfur Report (n 37) section VI (1-6).

45 Darfur Report (n 37) section VI (1-6).

46 Darfur Report (n 37) 645.

47 Darfur Report (n 37) 525.

48 The Report of the Commission of Inquiry into Post-Election Violence was handed over to president Mwai Kibaki and Prime Minister Raila Odinga on 15 October 2008 (Kenya Report).

49 Kenya Report (n 48). 
Commission, criminal cases should have been brought against persons bearing greatest responsibility for these crimes. ${ }^{50}$ The Commission extensively described that the post-election violence was not a mere juxtaposition of citizen-to-citizen opportunistic assaults, but it found that there were systematic attacks on civilians based on their ethnicity and political leanings. ${ }^{51}$ These findings were crucial to show that acts of violence in Kenya could amount to international crimes, as they were not sporadic or isolated. Indeed, the widespread or systematic nature of the attacks against the civilian population, which constitutes the contextual element of crimes against humanity under the Article 7 of the Rome Statute, draws a borderline between crimes against humanity falling within the jurisdiction of the ICC, and ordinary crimes, which are punishable only before domestic courts. The Commission also recommended the establishment of a special tribunal to prosecute crimes as a result of post-election violence. ${ }^{52}$

Similar to the Darfur Commission, the Waki Commission identified a list of alleged perpetrators and decided to not publish the list with names of alleged perpetrators in its report. ${ }^{53}$ This list was placed in a sealed envelope, which was sent to the Panel of African Eminent Personalities, with the recommendation to forward the names of likely suspects to the Prosecutor of the ICC, if the proposed special tribunal had not been set up. ${ }^{54}$

\subsubsection{The UNHRC Libya Commission}

The Libya Commission classified the investigated facts as international crimes. In its first report, the Commission had already found that Gadhafi forces had used excessive force against demonstrators in February 2011. ${ }^{55}$ In the final report, the Commission concluded that Gadhafi forces had committed crimes against humanity and war crimes in Libya. ${ }^{56}$ According to the Commission, acts of murder, enforced disappearance and torture had been perpetrated within the context of a widespread or systematic attack against a civilian population. ${ }^{57}$ The Commission also established additional violations as unlawful killing, individual acts of torture and ill-treatment, attacks on civilians, and rape. ${ }^{58}$ The fact-finding mission

${ }^{50}$ Kenya Report (n 48) pt III.

51 Kenya Report (n 48) pt V.

52 Kenya Report (n 48) pt v.

${ }^{53}$ Kenya Report (n 48) pt v.

${ }^{54}$ Kenya Report (n 48) pt v.

${ }_{55}^{5}$ Libya Report (n 25).

${ }^{56}$ Report of the International Commission of Inquiry on Libya, UN Doc A/HRC/19/68 (2 March 2012) (Final Libya Report).

${ }^{57}$ Final Libya Report (n 56) pt III (A-D).

58 Final Libya Report (n 56) pt III (B, D, F). 
stated also that the anti-Gadhafi forces (Thuwar) were responsible for war crimes and breaches of international human rights law. ${ }^{59}$ These forces, according to the Commission's findings, had committed unlawful killing, arbitrary arrest, torture, enforced disappearance, indiscriminate attacks, and pillage. ${ }^{60}$

The Commission also assessed the Libyan legislation and judicial system. In particular, it found that the domestic legislation did not adequately provide for the prosecution of international crimes. ${ }^{61}$ In addition, it established that Libya lacked a functioning justice system, so that international crimes would have likely been unpunished. ${ }^{62}$ Lastly, the Libya fact-finding mission decided not to include the names of the alleged perpetrators of international crimes in the final report, apart from senior figures who are publicly known. The Commission sent the confidential list of the alleged responsible for international violations to the High Commissioner for Human Rights. ${ }^{63}$

\subsubsection{The UNHRC Ivory Coast Commission}

As mentioned above, the Ivory Coast Commission was established to investigate the facts and circumstances surrounding the allegations of serious abuses and violations of human rights committed in Côte d'Ivoire following the presidential election of 28 November 2010, in order to identify those responsible for such acts and to bring them to justice. ${ }^{64}$ The Commission did not confine its role to assessing violations of human rights law, but also covered violations of international humanitarian law and international criminal law. ${ }^{65}$ Even if more superficially compared to other commissions examined in this section, the Ivory Coast Commission provided a legal characterisation of these abuses, by determining that war crimes and crimes against humanity had been committed at the relevant time. With regard to crimes against humanity, the Commission established that serious crimes such as murder and rape had been perpetrated within the context of a widespread and systematic attack against the civilian population, which was targeted on the basis of their supposed ethnicity or political sympathies. ${ }^{66}$

59 Final Libya Report (n 56) 810.

60 Final Libya Report (n 56) 810.

61 Final Libya Report (n 56) 771-774.

62 Final Libya Report (n 56) 779-784.

63 Final Libya Report (n 56) 760.

64 See UN Doc A/HRC/16/L.33 (18 March 2011) 10.

65 Rapport de la Commission d'enquête Internationale Indépendante sur la Côte d'Ivoire, UN Doc A/HRC/17/48 (1 July 2011) (Ivory Coast Report).

66 Ivory Coast Report (n 65) 91. 
The Commission did not provide detailed findings on why the post-election period amounted to a non-international armed conflict. Still, it concluded that some of the investigated abuses such as violence to life and person, cruel treatment and torture and humiliating and degrading treatment amounted to serious violations of common Article 3 to the Geneva Conventions, and as such, constituted war crimes under Article 8 of the Rome Statute. ${ }^{67}$ The Commission stressed that other serious violations of the laws and customs applicable in armed conflicts had been committed, such as intentionally directing attacks against the civilian population not taking direct part in hostilities, intentionally directing attacks against buildings, material, units and medical transports, attacks intentionally directed against personnel, installations, material, units or vehicles involved in a peace-keeping mission, intentionally directing attacks against buildings dedicated to religion, education and hospitals, looting of towns and villages, as well as rape and other forms of sexual violence. ${ }^{68}$

\subsection{COMMISSIONS OF INQUIRY AS NEW ACTORS ON THE STAGE OF THE ICC}

Before moving to an assessment of the impact of the work of commissions of inquiry on the ICC, it is necessary to remove the work of the Libya from the scope of this research. Indeed, although the scenario addressed by the Commission is the same of the Situation open before the ICC, I believe the investigation of the Libya fact-finding mission did not assume any relevance to the proceedings before the ICC. The investigation in Libya displays a lack of cooperation between the Commission of Inquiry and the ICC, as well as among other UN bodies, namely the Security Council and the Human Rights Council. The same Commission admitted that it consulted with the Court, but at the same time it stated no information had been shared with the ICC. Indeed, the UN Security Council referred the situation in Libya to the ICC the day after the Human Rights Council had established the Commission. ${ }^{69}$ Therefore, it appears that the work of the Libya commission of inquiry did not influence the Security Council's choice of referring the situation to the ICC. In other words, the UN Security Council's decision to trigger the ICC's jurisdiction under Article 13(b) was taken independent of the findings of the Commission.

In addition, the Prosecutor's decision to initiate the investigation was taken with unprecedented expeditiousness, only seven days after

67 Ivory Coast Report (n 65) 92-93.

68 Ivory Coast Report (n 65) 92-93.

69 UN Security Council Resolution 1970 (2011), UN Doc S/RES/1970(2011) (26 February 2011). 
the Security Council's referral. The same report of the Commission was published two weeks after the Prosecutor had submitted a request for three arrest warrants to the Pre-Trial Chamber. ${ }^{70}$ Thus, the Prosecutor did not have the possibility to use the Commission's report in supporting his request for warrants of arrest against Muammar Gaddafi, Abdullah Al Sanussi, and Saif Al-Islam Gaddafi.

Therefore, this section will focus on the relationship between the ICC and the Sudan, Ivory Coast and Kenya Commissions. In order to assess the impact of the commissions' sources on international criminal proceedings, it is necessary to discuss separately the different pre-trial stages before the ICC: (i) triggering the jurisdiction of the Court; (ii) authorisation of the investigation; (iii) issuance of arrest warrant or summon to appear; (iv) confirmation of the charges; (v) admissibility of the cases.

\subsubsection{Triggering the ICC Jurisdiction}

The UN Security Council, a state party or the Prosecutor may trigger the ICC's jurisdiction. ${ }^{71}$ The Sudan Situation was referred to the ICC by the Security Council, ${ }^{72}$ while in both the Kenya and Ivory Coast contexts the Prosecutor decided to initiate an investigation using his proprio motu powers under Article $15 .{ }^{73}$ In the Sudan, Kenya and Ivory Coast Situations, the Commissions' reports constituted the basis of the allegations leading to criminal prosecutions before the ICC. The detailed assessment of facts, which were made in particular by the Sudan and Kenya Commissions, raised the necessity of further investigation by the ICC Prosecutor and the need to ensure accountability for alleged international crimes committed.

Indeed, the Darfur Commission's work prompted the Security Council to approve Resolution 1593 (2005), which activated the jurisdiction of the ICC. ${ }^{74}$ The Security Council was persuaded by the detailed report of the Cassese Commission that international crimes had allegedly been committed. Therefore, the Commission's findings on the necessity of further investigations to be conducted by an international Prosecutor convinced the Security Council to approve its first referral to the ICC under Article 13(b) of the Rome Statute.

70 Libya Report (n 25).

71 Rome Statute, Art 13.

72 UN Security Council Resolution 1593 (2005), UN Doc S/RES/1593 (2005) (31 March 2005).

73 See Situation in the Republic of Kenya, Request for an Authorization of Investigation Pursuant to Article 15, ICC-01/09-3 (26 November 2009); Situation in the Republic of Ivory Coast, Request for an Authorization of Investigation Pursuant to Article 15, ICC-02/11-3 (23 June 2011).

74 UN Security Council Resolution 1593 (n 72). 
The Kenya situation can be considered as an emblematic example of the strict cooperation between the ICC and the Commission of Inquiry. Indeed, the Waki Commission had handed over a sealed envelope naming the suspects to former UN Secretary General Kofi Annan, requesting him to deliver the envelope to the ICC Prosecutor should the Kenyan authorities fail to establish a special court to try the likely suspects of crimes committed during the post-election violence. ${ }^{75}$ It was only following the failure by domestic authorities to establish this special tribunal that the ICC Prosecutor decided to use his powers under Article 15 of the Statute. ${ }^{76}$ Prior to this decision, the Prosecutor had agreed with the Kenyan government to not intervene, if the Special Tribunal had been established in order to seek accountability against persons bearing the greatest responsibility for crimes, particularly crimes against humanity, relating to the 2007 General Elections in Kenya. ${ }^{77}$ After receiving the sealed envelope and supporting material compiled by the Commission, on 26 November 2009 the ICC Prosecutor requested the Pre-Trial Chamber II to grant the authorisation to start an investigation on the crimes against humanity allegedly committed during the post-election violence in Kenya. ${ }^{78}$ In his request for the authorisation under Article 15, the same Prosecutor extensively used the Commission's allegations regarding the perpetration of crimes against humanity in Kenya.

With respect to the Ivory Coast Situation, the UN Commission's report is not the main fact-finding document, as it constituted one of several materials submitted by third parties investigating the post-election violence in Ivory Coast. Together with reports presented by a number of nongovernmental organisations, the Commission's materials were used by the Prosecutor as evidence for the contextual elements of an 'attack' for the purposes of establishing the commission of crimes against humanity, and of a non-international armed conflict with regard to the existence of war crimes. ${ }^{79}$

\subsubsection{Decision of the Pre-Trial Chamber to Authorise the Investigation}

Article 15(4) of the Rome Statute provides that

If the Pre-Trial Chamber, upon examination of the request and the supporting material, considers that there is a reasonable basis to proceed with an

75 Kenya Report (n 48) pt V.

76 Situation in the Republic of Kenya (n 73).

77 ICC, Agreed Minutes of the meeting between Prosecutor Moreno-Ocampo and the delegation of the Kenyan Government, 3 July 2009.

78 Situation in the Republic of Kenya (n 73).

79 Situation in Côte d'Ivoire (n 73) 61-173. 
investigation, and that the case appears to fall within the jurisdiction of the Court, it shall authorise the commencement of the investigation...

In light of the low standard of proof required at this stage of proceedings, all the evidentiary materials presented by the Prosecutor are subject to a minimum judicial review by the competent Pre-Trial Chamber.

In its decision to authorise the investigation into the Ivory Coast situation, the Pre-Trial Chamber II accepted the Prosecutor's request. ${ }^{80}$ In line with the OTP allegations, the Chamber made a significant use of the Commission's report to establish that there was a reasonable basis to believe that the contextual element of war crimes, consisting of the existence of an armed conflict of a non-international character, was met. ${ }^{81}$

The Waki Commission's report had a noteworthy influence on the same decision of the Pre-Trial Chamber authorising the Prosecutor to initiate the investigation in Kenya. ${ }^{82}$ First, the Pre-Trial Chamber used the Commission's sources to define the temporal, material and territorial parameters of the investigation, which could have been conducted by the Prosecutor. ${ }^{83}$ Second, the fact-finding mission's report assumed significant relevance to the Pre-Trial Chamber's ascertainment of the chapeau elements of crimes against humanity, as: (i) the attack directed against the civilian population; ${ }^{84}$ (ii) the organisational policy; ${ }^{85}$ (iii) the widespread and systematic nature of the attack; 86 (iv) the link between the individual conduct and the attack. ${ }^{87}$ Similarly, the Chamber relied on the Commission's information also to establish that there was a reasonable basis to believe that murder, rape, forcible transfer, and other inhumane acts causing serious injuries had been committed within the context of the widespread and systematic attack against the civilian population. ${ }^{8}$

\subsubsection{Issuance of Arrest Warrant and Summons to Appear}

As already mentioned, the Sudan, Kenya, and Ivory Coast Commissions each submitted a list of alleged perpetrators of international crimes to the

80 Situation in Côte d'Ivoire, Decision Pursuant to Article 15 of the Rome Statute on the Authorization of an Investigation into the Situation in the Republic of Côte d'Ivoire, ICC-02/11-14 (3 October 2011) (Authorisation Investigation Côte d'Ivoire).

81 Authorisation Investigation Côte d'Ivoire (n 80).

82 Decision Pursuant to Article 15 of the Rome Statute on the Authorization of an Investigation into the Situation in the Republic of Kenya, ICC-01/09-19 (31 March 2010) (Authorisation Investigation Kenya).

83 Authorisation Investigation Kenya (n 82) 201-11.

84 Authorisation Investigation Kenya (n 82) 100-14.

85 Authorisation Investigation Kenya (n 82) 115-28.

86 Authorisation Investigation Kenya (n 82) 129-34.

87 Authorisation Investigation Kenya (n 82) 135-38.

88 Authorisation Investigation Kenya (n 82) 139-71. 
ICC Prosecutor. However, they decided to keep these lists confidential. Whether the people identified by the Prosecutor as alleged perpetrators were the same as those listed in the commissions' materials is a matter of speculation. However, we cannot fail to note that the profile of the likely suspects identified by the commissions is very similar to those people prosecuted before the ICC. This is true with regard to the Darfur Commission, which pointed to the responsibility of members of the government and Janjaweed Militias for crimes against humanity and war crimes. ${ }^{89}$ Indeed, since 2009, most senior leaders of the State and Janjaweed have been accused by the Prosecutor of international crimes. ${ }^{90}$ The Commission had also stressed the responsibility of members of two rebel groups: the Sudan Liberation Army (SLA) and Justice for Equality Movement (JEM). In line with the Commission's findings, in 2010, the Prosecutor started an investigation against Banda and Jerbo, considered as the military commanders respectively of JEM and SLA. ${ }^{91}$

In Ivory Coast, the relationship between the Commission's work and the suspects against whom the Prosecutor brought a case appears evident. Indeed, the public report frequently mentioned the role played by the former President of Ivory Coast, Laurent Gbagbo, and Charles Blè Goude', former Minister of Youth Affairs. ${ }^{92}$ In particular, the Commission reported the involvement of the militias and mercenaries working for Gbagbo in the commission of abuses during the post-election violence. ${ }^{93}$ Gbagbo and Goudè were committed to trial in 2014. ${ }^{94}$

It is worth to remembering that third party fact-finding sources constitute indirect evidence, whose probative value appears to be sufficient in order to establish the standard of proof under Article 58, namely that there are reasonable grounds to believe that the suspect has committed the crimes falling within the Rome Statute. Indirect evidence encompasses hearsay evidence, reports of international and non-governmental organisations (NGOs), as well as reports from national agencies, domestic intelligence services and the media. ${ }^{95}$ Similar to the stage of proceedings

89 Darfur Report (n 37) 630-39.

90 See the Darfur cases: Prosecutor v Omar Hassan Ahmad Al Bashir ICC-02/05-01/09; Prosecutor $v$ Ahmad Muhammad Harun ('Ahmad Harun') and Ali Muhammad Ali Abd-Al-Rahman ('Ali Kushayb') ICC-02/05-01/07; Prosecutor v Abdel Raheem Muhammad Hussein ICC-02/05-01/12.

91 Prosecutor $v$ Abdallah Banda Abakaer Nourain ICC-02/05-03/09. Proceedings against Saleh Mohammed Jerbo Jamus were terminated by Trial Chamber IV on 4 October 2013 after receiving evidence pointing towards his death.

92 Ivory Coast Report (n 65) 23-28.

93 Ivory Coast Report (n 65) 23-28.

94 See Prosecutor $v$ Laurent Gbagbo, Decision on the Confirmation of Charges against Laurent Gbagbo, ICC-02/11-01/11-656-Red (12 June 2014); Prosecutor v Charles Blé Goudé, Decision on the Confirmation of Charges against Charles Blé Goudé, ICC-02/11-02/11-186 (11 December 2014).

95 Prosecutor $v$ William Samoei Ruto, Henry Kiprono Kosgey and Joshua Arap Sang, Decision on the Confirmation of Charges Pursuant to Article 61(7)(a) and (b) of the Rome Statute, ICC01/09-01/11-373 2 (23 January 2012) 69. 
regarding the authorisation to open an investigation under Article 15, Article 58 entails a low standard of proof and low level of judicial oversight in terms of arrest warrant or summons to appear. Article 58 of the Rome Statute provides two requirements for the issuance of a warrant of arrest: there must be reasonable grounds to believe that a person has committed a crime within the jurisdiction of the Court and that an arrest is necessary. If the arrest warrant is not deemed necessary, as one of the three conditions provided under Article 58(1)(b) should fail, a summons to appear may be issued. ${ }^{96}$ The issuance of an arrest warrant or summons to appear marks the beginning of a case before the ICC.

As stated in the Lubanga and Katanga cases, the first limb for the purposes of the issuance of an arrest warrant is a two-fold test, which requires that there are reasonable grounds to believe: (1) that one of the crimes within the ICC jurisdiction has been committed; and (2) that the alleged perpetrator is criminally liable for such a crime under one of the modes of liability enshrined in the Rome Statute. ${ }^{97}$

An examination of the different cases related to the Situation in Sudan show how the commission of inquiry's information assumed significant probative value in establishing the perpetration of one of the crimes within the jurisdiction of the ICC. In the Darfur cases, the OTP had notably relied on the Cassese Commission's material in its applications under Article $58 .{ }^{98}$ In the application for an arrest warrant against Hussein, the evidence provided by the OTP included open source material, witness statements, material obtained from the Darfur Commission of Inquiry, and documents provided by the government of Sudan. ${ }^{99}$ In the application for summons to appear in the Harun and Kushayb case, the Prosecutor admitted to having 'benefited greatly from the information furnished by the UNCOI' and the National Commission of Inquiry. ${ }^{100}$ The Prosecution

\footnotetext{
96 According to the Rome Statute, Art 58(1)(b), the arrest is necessary when of the following condition is met: '(i) To ensure the person's appearance at trial; (ii) To ensure that the person does not obstruct or endanger the investigation or the court proceedings; or Where applicable, to prevent the person from continuing with the commission of that crime or a related crime which is within the jurisdiction of the Court and which arises out of the same circumstances.'

97 Situation in the Republic of Congo, Decision on the Prosecutor's Application for Warrants of Arrest, Article 58, Lubanga, ICC-01/04-01/07 (10 February 2006) 93; Decision on the Evidence and Information Provided by the Prosecution for the Issuance of a Warrant of Arrest for Germain Katanga, Katanga, ICC-01/04-01/07 (5 November 2007) 24.

98 See Situation in Darfur, the Sudan, Public Redacted Version of the Prosecutor's Application under Article 58, Al Bashir, ICC-02/05-157-AnxA (14 July 2008).

99 Situation in Darfur, the Sudan, Public Redacted Version of Prosecutor's Application under Article 58 filed on 2 December 2011 with Public Annexes 1 \& 2, Hussein, ICC-02/05-237-Red (24 January 2012) 7.

100 Situation in Darfur, the Sudan, Public Redacted Version Prosecutor's Application under Article 58(7), ICC-02/05-56, Harun and Ali Kushayb (27 February 2007).
} 
stated that he had 'evaluated the conclusions of the UNCOI and the NCOI, and the materials underlying the findings of those commissions' ${ }^{101}$

In light of this, the Pre-Trial Chamber mainly followed the Prosecutor's reasoning and recognised the relevance of the Commission's sources to the issuance of the arrest warrants. Still, a significant difference between the Chamber's findings and the Prosecutor's application is related to the crime of genocide. Indeed, in the first arrest warrant decision against Al Bashir, the Pre-Trial Chamber appeared more persuaded by the Commission's findings when it rejected the Prosecutor's submissions that there were reasonable grounds to believe that genocide had been committed in Darfur. ${ }^{102}$

In particular, in the Al Bashir case, the Pre-Trial Chamber I used the Commission's materials to establish the contextual element and the underlying offences of both war crimes and crimes against humanity. ${ }^{103}$ In the Darfur cases, the Pre-Trial Chamber I relied on the Commission's sources, not only to find that there were reasonable grounds to believe that crimes had been committed, but also in order to establish a link between the perpetration of these crimes and the alleged perpetrators. ${ }^{104}$

It appears more problematic to establish the weight of the commissions' findings in the Kenya and Ivory Coast cases. This is due to the fact that the prosecutorial applications for summons to appear in the Kenya cases are heavily redacted, ${ }^{105}$ while the OTP's request for arrest warrants related to the situation in Ivory Coast are still under seal. This prevents us from knowing which types of evidence have been presented and in particular, the role that the commissions' documents may have played in supporting the Prosecutor's applications.

Nevertheless, in the case against Gbagbo, it is the Pre-Trial Chamber's decision on the arrest warrant to reveal that the Prosecutor had mainly relied on third party sources, in particular reports by several NGOs. ${ }^{106}$

101 ibid 13: 'On 5 April 2005, the Prosecution received more than 2,500 items, including documentation, video footage and interview transcripts which had been gathered by the UNCOI, together with a sealed envelope containing the conclusions reached by that commission as to persons potentially bearing criminal responsibility for the crimes in Darfur'.

102 See Prosecutor v Omar Al Bashir, Decision on the Prosecution's Application for a Warrant of Arrest against Omar Hassan Ahmad Al Bashir, ICC-02/05-01/09-3 (4 March 2009) 204-05.

103 ibid 55-109.

104 See, inter alia, Situation in Darfur (n 100) 209-23.

105 Situation in the Republic of Kenya, Prosecutor $v$ William Samoei Ruto, Henry Kiprono Kosgey and Joshua Arap Sang, Prosecutor's Application Pursuant to Article 58 as to William Samoei Ruto, Henry Kiprono Kosgey and Joshua Arap Sang, ICC-01/09-30-Red2 (15 December 2010); Situation in the Republic of Kenya, Prosecutor's Application Pursuant to Article 58 as to Francis Kirimi Muthaura, Uhuru Muigai Kenyatta and Mohammed Hussein Ali, ICC-01/0931-Red2 (15 December 2010).

106 Prosecutor $v$ Laurent Koudou Gbagbo, Decision on the Prosecutor's Application Pursuant to Article 58 for a warrant of arrest against Laurent Koudou Gbagbo, ICC-02/11-01/11-9-Red (30 November 2011). 
In line with the Prosecutor's application, the Commissions' information, together with a number of documents provided by NGOs, was persuasive to the Pre-Trial Chamber III's findings, particularly with regard to the establishment of a widespread or systematic attack against the civilian population and of individual conduct constituting crimes against humanity, as inhumane acts and murder. ${ }^{107}$ In the case against Simone Gbagbo, in the establishment of criminal liability for the crimes alleged by the Prosecutor, the Chamber used, inter alia, the UNHRC's report to conclude that the suspect had played a key role in recruiting, arming and integrating thousands of volunteers and enlisting them into the Defense and Security Forces FDS chain of command. ${ }^{108}$

\subsubsection{Confirmation of Charges}

The confirmation of charges constitutes one of the main innovations introduced by the drafters of the Statute in the field of international criminal justice. ${ }^{109}$ Statutes of other international or internationalised criminal tribunals do not contain such a procedure. The confirmation of charges is the stage at which a Pre-Trial Chamber makes a determination whether the case is to be sent for trial. ${ }^{110}$ The Prosecutor and the Defence are the parties to the confirmation procedure and, as such, they may submit their evidence and call witnesses. ${ }^{111}$ Pursuant to Article 61(6) of the Statute, the suspect may also object to the charges, challenge the evidence presented by the Prosecutor and submit evidence. In addition, victims who have suffered personal harm linked to the charges against the accused may participate in the confirmation proceedings through their legal representatives. ${ }^{112}$

In contrast to the arrest warrant or summons to appear procedure, the confirmation of charges is deliberately envisaged as an adversarial hearing, whereby the person charged has the right to be present and contest the evidence before a Pre-Trial Chamber composed of three judges. Thus, ICC Pre-Trial Chambers are vested with the authority to assess

107 ibid 28-61.

108 Prosecutor $v$ Simone Gbagbo, Decision on the Prosecutor's Application Pursuant to Article 58 for a Warrant of Arrest against Simone Gbagbo ICC-02/11-01/12-2-Red (2 March 2012) 33.

109 T Mariniello, 'Questioning the Standard of Proof: The Purpose of the ICC Confirmation of Charges Procedure' (2015) 13 Journal of International Criminal Justice 579.

110 Rome Statute, Art 61.

111 Rome Statute, Arts 61(5) and 61(6)(c).

112 Rome Statute, Art 68(3). 
evidence, including the power to determine its relevance, admissibility, and weight. ${ }^{113}$

These factors characterising the confirmation of charges procedurethe higher standard of proof, the judicial scrutiny of the evidence submitted by the parties and the role of the Defence, who can challenge the prosecutorial evidence-have the effects of reducing the impact of indirect evidence, including the commissions' information, on the decision to commit an individual to trial. The Darfur cases have not reached the stage of confirmation of charges before the ICC. However, the Kenya and Ivory Coast decisions on the confirmation of charges reveal how third party factfinding sources have a lesser weight in the proceedings, if compared to the previous stage relating to the arrest warrant or summons to appear. ${ }^{114}$

In the Kenya cases, the Chamber clarified that the decision on the confirmation of charges cannot be based solely on a piece of indirect evidence, ${ }^{115}$ whilst a single piece of direct evidence may be decisive for the Chamber's determination. ${ }^{116}$ According to the Chamber, 'more than one piece of indirect evidence, which has low probative value, is preferable to prove an allegation to the standard of substantial grounds to believe' ${ }^{117}$

Saying that, in both cases, it appears that the majority (Judge Trendafilova and Judge Tarfusser) used the commissions' materials as corroborating evidence of witness statements submitted by the Prosecutor. In

113 For instance, r 63(2) of the Rules and Procedures of Evidence establishes that any Chamber, including the Pre-Trial Chamber, 'shall have the authority, in accordance with the discretion described in Article 64, paragraph 9, to assess freely all evidence submitted in order to determine its relevance or admissibility in accordance with Article 69 ...'. In addition, Article 69(4) of the Statute, which applies also at the confirmation hearing', provides that ' $[t]$ he Court may rule on the relevance or admissibility of any evidence, taking into account, inter alia, the probative value of the evidence and any prejudice that such evidence may cause to a fair trial or to a fair evaluation of the testimony of a witness, in accordance with the Rules of Procedure and Evidence'.

114 With regard to the situation in Kenya, see Prosecutor $v$ William Samoei Ruto, Henry Kiprono Kosgey and Joshua Arap Sang, Decision on the Confirmation of Charges Pursuant to Article 61(7)(a) and (b) of the Rome Statute, ICC-01/09-01/11-373, Pre-Trial Chamber II (23 January 2012) (Ruto, Kosgey and Sang Confirmation Decision); Prosecutor v Francis Kirimi Muthaura, Uhuru Muigai Kenyatta and Mohammed Hussein Ali, Decision on the Confirmation of Charges Pursuant to Article 61(7)(a) and (b) of the Rome Statute, ICC-01/09-02/11-382-Red (23 January 2012) (Muthaura, Kenyatta and Ali Confirmation Decision). With respect to the situation in Ivory Coast, see Prosecutor v Charles Blè Goudè, Decision on the Confirmation of Charges against Charles Blè Goudè, ICC-01/09-02/11-382-Red (23 January 2012); Prosecutor v Laurent Koudou Gbagbo, Decision on the Confirmation of Charges against Laurent Gbagbo, Gbagbo (ICC-02/11-01/11-656-Red), Pre-Trial Chamber I (Gbagbo Confirmation Decision) (12 June 2014); Prosecutor v Laurent Koudou Gbagbo, Decision adjourning the hearing on the confirmation of charges pursuant to Art 61(7)(c)(i) of the Rome Statute, ICC-02/11-01/11-432, PreTrial Chamber I (3 June 2013) (Gbagbo Adjournment Decision).

115 Ruto, Kosgey and Sang Confirmation Decision (n 114) 74.

116 Ruto, Kosgey and Sang Confirmation Decision (n 114) 74.

117 Ruto, Kosgey and Sang Confirmation Decision (n 114) 75. 
particular, in the case against Muthaura, Kenyatta and Ali, the Pre-Trial Chamber found the Commission's documents persuasive as corroborating evidence in relation to the underlying offences of crimes against humanity, murder, deportation and other inhuman acts. ${ }^{118}$

In the Gbagbo case, the Pre-Trial Chamber adopted an even stricter approach in the assessment of the probative value of indirect evidence for the confirmation of charges. ${ }^{119}$ The Chamber expressed its concern that the Prosecutor had relied heavily on NGO reports and press articles with regard to key elements of the case, including the contextual elements of crimes against humanity. ${ }^{120}$ The Chamber found that these pieces of indirect evidence did not constitute the fruits of a proper investigation conducted by the Prosecutor in accordance with Article 54(1)(a) of the Statute. ${ }^{121}$ According to the majority of judges sitting in the Pre-Trial Chamber, NGO reports and press articles may be a useful means to clarify the historical context of a conflict situation. ${ }^{122}$ However, they do not usually constitute a valid substitute for the type of evidence that is required to meet the evidentiary threshold for the confirmation of charges. ${ }^{123}$ This is due to the fact that NGOs reports are mainly based on anonymous hearsay, which cannot be investigated and challenged by the Defence. The Chamber also expressed its doubts that anonymous hearsay contained in NGOs' reports could be useful to corroborate other types of indirect evidence, since it is problematic to establish whether these sources are truly independent of each other. ${ }^{124}$

\subsubsection{Admissibility}

The Darfur Commission condemned the inaction of both the Sudanese authorities and the rebels to prosecute and try those allegedly responsible for the serious crimes committed. ${ }^{125}$ It found that the government had not put in place any real and effective response to large-scale criminality linked to the armed conflict. ${ }^{126}$ Therefore, considering the nature of international crimes, which are committed by state officials or with their complicity, as well as the shortcomings of the Sudanese criminal justice

118 Muthaura, Kenyatta and Ali Confirmation Decision (n 114) 240, 247, 262, 276.

119 Gbagbo Adjournment Decision (n 114).

120 Gbagbo Adjournment Decision (n 114) 35.

121 Gbagbo Adjournment Decision (n 114) 35.

122 Gbagbo Adjournment Decision (n 114) 35.

123 Gbagbo Adjournment Decision (n 114) 35.

124 Gbagbo Adjournment Decision (n 114) 30.

125 Darfur Report (n 37) 567-68.

126 Darfur Report (n 37) 567-68. 
system, the Commission concluded that Sudan was unwilling and unable to prosecute and try the alleged offenders. ${ }^{127}$ The Kenya Report emphasised the weaknesses and difficulties of the domestic criminal justice system to investigate and prosecute crimes allegedly committed during the post-election violence. ${ }^{128}$ The Ivory Coast Commission highlighted that domestic authorities had failed to adopt any measures to put an end to impunity. ${ }^{129}$

This type of information by fact-finding commissions on states' unwillingness to prosecute and investigate alleged perpetrators of serious crimes, or on the state of domestic justice systems, may be very useful in making a preliminary evaluation of the admissibility of a case before the ICC. The ICC could be called to deal with questions related to the admissibility from early stages of the proceedings up until trial. At the situation stage, the prosecutorial decision to start the investigation and prosecution entails also the evaluation of the admissibility of the case under Article $17 .{ }^{130} \mathrm{Sim}$ ilarly, the Pre-Trial Chamber's authorisation for the Prosecution to start the investigation under Article 15 encompasses also the examination of the admissibility conditions. At this stage of the proceedings, where there is no identified suspect, the admissibility test requires an assessment as to whether the state is conducting, or has conducted, national proceedings in relation to a potential case, namely in relation to the groups of persons and the crimes allegedly committed during those incidents. ${ }^{131}$ Therefore, the material provided by fact-finding commissions might be crucial in providing significant information on whether the relevant state is willing and/or able to investigate and prosecute certain categories of potentially accused, as those identified as alleged perpetrators by the same commissions.

Therefore, commissions of inquiry's findings might also be used by the ICC to evaluate the quality and state of a domestic judicial system, in order to establish its capability to conduct effective criminal proceedings. Indeed, as it stems from the detailed reports in Darfur and Kenya, the work of the commissions' may provide the ICC with useful insights on the shortcomings of a domestic judicial system, which would be unable to carry out impartial criminal proceedings, also in light of the general security situation.

127 Darfur Report (n 37) 568.

128 Kenya Report (n 48) Ch 12.

129 Ivory Coast Report (n 65) 120.

130 According to the Rome Statute, Art 53(1)(b) 'In deciding whether to initiate an investigation, the Prosecutor shall consider whether: the case is or would be admissible under Article 17'. Under Art 53(2)(b), 'If, upon investigation, the Prosecutor concludes that there is not a sufficient basis for a prosecution because: The case is inadmissible under Article 17'.

131 See, inter alia, Authorisation Investigation Kenya (n 82) 48-50. 


\subsection{A CONCLUDING APPRAISAL OF THE RELATIONSHIP BETWEEN FACT-FINDING SOURCES AND ICC PROCEEDINGS}

This paper assessed the influence of the information provided by commissions of inquiry on the pre-trial proceedings before the ICC. Even if commissions' material is not binding on international criminal tribunals, their investigations appeared to be very persuasive with regard to the Prosecutor's decisions as well as to the Chamber's findings. The analysis conducted in section 7.5 shows how the significance of the material provided by commissions of inquiry before the ICC varies in the course of proceedings on the basis of the rising standards of proof. As indirect evidence, fact-finding materials appeared to have a stronger impact on the ICC during those preliminary phases of the proceedings that require the lowest standards of proof to be satisfied. Indeed, the Rome Statute establishes four different, progressively higher, evidentiary thresholds in Articles 53(1)(a), 58(1), 61(7) and 66(3). ${ }^{132}$ The lowest test is provided in the early stage of the proceedings, namely, in Article 53(1)(a) regarding the initiation of an investigation, where the Prosecutor has to assess whether or not there is a 'reasonable basis to believe that a crime within the jurisdiction of the Court has been or is being committed' (emphasis added). ${ }^{133}$ At the next, higher, standard the issuance of a warrant of arrest pursuant to Article 58(1) requires that there are 'reasonable grounds to believe that the person has committed a crime within the jurisdiction of the Court'. Situated immediately above, there is Article 61(7) providing a 'substantial grounds to believe' test for the purposes of the confirmation of charges. Finally, the highest threshold is enshrined in Article 66(3), according to which 'in order to convict the accused, the Court must be convinced of the guilt of the accused beyond reasonable doubts'.

By providing the first comprehensive analysis of the relevant pre-trial jurisprudence related to the situations in Sudan, Kenya, and Ivory Coast, this paper confirms Stahn and Jacobs' argument that the impact of factfinding sources decreases in the progression of the proceedings. ${ }^{134}$ They

132 See Ruto, Kosgey and Sang Confirmation Decision (n 114) 40. However, in the Bemba Confirmation Decision, Pre-Trial Chamber II found that there are only three evidentiary threshold, by omitting any references to Art 53(1)(a). In this regard, see Prosecutor v JeanPierre Bemba Gombo, Decision Pursuant to Article 61(7)(a) and (b) of the Rome Statute on the Charges of the Prosecutor Against Jean-Pierre Bemba Gombo, ICC-01/05-01/08-424 (15 June 2009) 27.

133 The same evidentiary threshold is enshrined in Art 15 with regard to the Pre-Trial Chamber's authorisation for the Prosecutor to commence investigations proprio motu.

${ }^{134}$ C Stahn and D Jacobs, 'Human Rights Fact-Finding and International Criminal Proceedings: Towards a Polycentric Model of Interaction', Grotius Centre Working Paper Series, 2014/017-ICL. 
also bring into the picture other factors, such as 'the prosecutorial discretion in relation to choice of situations and cases, the scope of defendants' rights and the balance between Judge-led- and Prosecution-led inquiry' ${ }^{\prime}{ }^{135}$ In other words, the relevance of commissions' information is more significant during those stages of proceedings where the Prosecutor enjoys more discretion and the Defence does not have the possibility to challenge the evidence submitted by fact-finding commissions. This is true in relation to the phase related to the prosecutorial choice of situations to investigate, when formally a suspect has not yet been identified. By contrast, the use of commissions' investigations starts to appear less significant at the confirmation of charges stage of proceedings, which is deliberately envisaged as an adversarial hearing, whereby the person charged has the right to be present and contest the evidence before a Pre-Trial Chamber composed of three judges.

Therefore, the work of the commissions of inquiry constituted a significant source at the pre-investigative phase, by offering a general overview of the situation, and revealing the (alleged) existence of the contextual elements of international crimes. With a focus on the situations in Sudan, Kenya and Ivory Coast, this study examined how the commissions' sources assumed, even if in different degrees, relevance to paving the way to proceedings before the ICC. In Sudan, the Commission's investigation played a key role within the context of the UN Security Council's decision to refer the situation to the ICC. The examination of the situation in Kenya showed the strict cooperation between the Commission and the Court. The Commission's information had a significant weight on the Prosecutor's decision to open an investigation, by using his proprio motu powers under the Article 15 of the Rome Statute. With respect to the Ivory Coast, the relevance of the UN commission of inquiry's information to the ICC's proceedings appeared less evident. Still, the commission of inquiry's information constituted one of the several reports by third parties, which were used by the Pre-Trial Chambers in order to authorise the Prosecution to open the investigation.

In addition, this chapter assessed also the role of commissions' materials during the investigative stage before the ICC. It ascertained that the decision by the Pre-Trial Chamber under Article 58 was strongly influenced by third party sources, as it follows an ex parte application conducted with the absence of the Defence, which cannot object to the relevance and admissibility of the evidence. Particularly in the Darfur cases, the commissions' information was used not only to establish that there were reasonable grounds to believe that the crimes had been committed, but also to establish the link between this commission and the alleged perpetrators. 
To conclude, as commissions' sources appeared to assume a central relevance in the issuance of arrest warrants or summons to appear under Article 58, it is important that commissions of inquiry are provided with clear and transparent guidelines and procedures, considering, in most circumstances, the anonymous and unknown nature of the witnesses. However, it is no less certain that commissions of inquiry are not mandated to establish whether individuals are guilty. Thus, in the application for an arrest warrant, it is of the utmost importance that the Prosecutor does not become a mere rubber stamping of commissions' findings or, more generally, that she does not only rely on inferences or types of indirect evidence. She should rather always be able to corroborate with her own evidence the information of the commissions of inquiry.

This is necessary in light of the strong impact that the issuance of the arrest warrant has on the fundamental rights of an individual, by bringing a restriction to his personal liberty. The deprivation of personal liberty could also last for a long time before the Pre-Trial Chamber decides whether or not to confirm the charges. In addition, an arrest warrant or summons issued by international criminal tribunals may also have strong political implications, when the alleged perpetrator is a political leader. ${ }^{136}$ Also, with respect to the application under Article 58, the fact-finding sources should always be corroborated by the Prosecutor's own evidence, considering that the commissions' information is confined to the ascertainment of the contextual elements and actus reus of international crimes, whilst it generally puts little emphasis on the attribution of criminal liability. ${ }^{137}$ Indeed, in establishing that the investigated facts amount to international crimes, the fulfillment of further elements of international crimes, such as modes of liability and mens rea, receives very poor attention by fact-finding missions.

136 See M Marsden and C Chung, 'Reasonable Grounds to Believe: An Unreasonably Unclear Evidentiary Threshold in the Rome Statute' (2015) 13 Journal of International Criminal Justice 555, 573.

137 C Harwood, 'Human Rights in Fancy Dress? The Use of International Criminal Law by Human Rights Council Commissions of Inquiry in Pursuit of Accountability' (2015) 58 Japanese Yearbook of International Law 71. 